\title{
Digital Propaganda: The tyranny of ignorance
}

\begin{abstract}
The existence of propaganda is inexorably bound to the nature of communication and communications technology and the widespread availability of digital communication tools allows a much larger number of individual citizens to produce and distribute propaganda on a mass scale than has been possible in previous eras. Mass communication by citizens has been heralded as a means to counter elite propaganda; however, it also provides a forum for deception and misinformation, as well as aggression and hostility. The extremist group Britain First has used Facebook as a way to propagate hostility towards Muslims, immigrants and social security claimants in the form of infographic memes, leading to a backlash from sites antithetical to their message. This paper provides a memetic analysis, addressing factors such as persuasion, organisation and self-correcting online narratives which have been raised in literature on propaganda and new media; arguing that propaganda can be best understood as an evolving set of techniques and mechanisms which facilitate the propagation of ideas and actions. This allows for the means by which political narratives spread to change in response to their social, political and technological environment as well as allowing for both 'honest' propaganda and mass deception through collective ignorance.
\end{abstract}

Keywords: Propaganda. Meme. Social-Media. Facebook. Islamophobia. Racism. 


\section{Digital Propaganda: The tyranny of ignorance}

Propaganda's enigmatic position within scholarship has been documented at length by those such as Nicholas J. O'Shaugnessy (2004) who have sought to pin down a consistent definition of the concept from within the myriad studies which have addressed it. This paper will argue in concert with Bakir et al's (2015) work that propaganda remains a relevant category for study which would benefit from a more systematic theoretical framework, but will also address two aspects of the framework proposed in that study as potentially problematic for the analysis of viral and/or digital propaganda. Bakir et al's paper argues that propaganda can be seen as a coercive and/or manipulative subset of Organised Persuasive Communication (OPC), a category which also includes forms of communication which are informational and consensual and therefore not considered by the authors to be propaganda. This paper will contend that two aspects of this, organisation and persuasion may not hold true for all examples of online propaganda and that propagation is the more logical overarching framework for a comprehensive theory of propaganda. It will also propose an alternative model based on memetic theory which will help to overcome these difficulties.

This paper will begin by introducing memetic theory as an appropriate way to study propaganda in general and digital propaganda specifically, before outlining the methodological considerations applied to a case study which will focus on the use of Facebook by the right wing extremist group Britain First (2015a, 2015b) and the subsequent responses by their online detractors. Whilst in this instance there will be a focus on the internet or pop-cultural meme as it is relevant to the case study, this paper will argue that memetics has considerable analytical and methodological potential with respect to scholarly work on propaganda, and this is not limited to digital communications or internet memes. This paper will also seek to challenge the assertions made by some such as Paul Mason (2013a) and Johnathan Zittrain (2008), that the democratic nature of digital communication provides a self-correcting mechanism to counter inaccurate or nefarious instances of online propaganda, drawing on discussions of echo chambers and 'trench warfare' within digital communications. In order to problematise notions of organisation and persuasion, the paper will draw attention to the often decentralised and chaotic nature of digital propaganda, in which the perpetuation of ideologies can be highly disorganised when compared to the professionalised propaganda produced by states and corporate entities. It will also discuss the way in which echo chamber and trench warfare dynamics result in propaganda targeted at those already sympathetic to an ideology, with the purpose being the affirmation of beliefs which are already present, with persuasion (where it is present at all) limited specifically to action. With contemporary propaganda, this often includes the actions involved in further replicating propaganda through social and digital networks, further emphasising the potential of propagation as the universal underlying principal 
with the potential to unify the many disparate approaches to understanding propaganda as a concept.

\section{Memes, memetics and propaganda}

The term 'meme' was originally coined by Richard Dawkins (2006a) in a speculative aside to his discussion of genetics in The Selfish Gene. His purpose was to demonstrate that the power of evolutionary creation seen in the biological world was not necessarily isolated in that world but the result of the existence of a specific entity which he referred to as a 'replicator', defined as any unitary entity capable of creating copies of itself with occasional deviations. In genetics the gene fulfils this function as the building block of the evolutionary process, in culture, Dawkins (2006a) argued, this role is fulfilled by the 'meme', examples of which included stories, jokes and methods for the construction of artefacts. A meme in this academic context can be any aspect of culture provided that it is potentially replicable as an individual unit. In terms of online analysis every Facebook post or tweet can be considered a meme, as can specific hashtags or blog posts. Although there has been criticism of the lack of specificity in size when memes are defined in this way, attempts at categorisation and clarification have also been made with Blackmore (1999) arguing that as long as it can be replicated as a distinct unit, size should not be a definitional problem for a meme. This study will adhere to this definition as well as making a specific distinction between the academic meme discussed by scholars such as Dennett $(1996,2003)$, Blackmore (1999) and Dawkins (2006b, 2006a), and the pop-cultural or Internet meme which is a more specific sub-category relevant to this case study.

Whilst initial hopes for a science of memetics largely evaporated around the middle of the 2000s with the death of the one discipline's one dedicated journal (Edmonds, 2005), interest has been maintained in relation to so 'Internet memes' which includes hared online jokes and other digital material which are subject to forms of evolutionary change (Shifman and Thelwall, 2009, Ward, 2008, Weng et al., 2012, Rintel, 2013, Christensen, 2011, Bauckhage et al., 2013, Shifman, 2012). The term pop-cultural meme was coined as a more accurate distinction with the academic meme as some have suggested that the Internet meme must originate online, rather than simply proliferating there (see discussion in Sparkes-Vian, 2015). The significant difference between the two is that academic memes are memes simply by virtue of their capacity to replicate as a coherent unit, whilst a pop-cultural meme is often defined in relation to its popularity. There are numerous recognisable variations on the Internet or pop-cultural meme of which the infographic is amongst the most 
recognisable, usually taking the form of a captioned image, with specific images and text formulations also replicated as distinct memes (Rintel, 2013, IMD, 2014).

The use of memetics in order to analyse propaganda is initially promising because of the relationship between propaganda and the notion of ideological propagation. Memetic theory deals specifically with unitary texts and ideas and their capacity to effectively replicate (or disperse in the form of copies) throughout a given socio-political or cultural environment (Blackmore, 1999). Propaganda can be seen essentially as a means by which certain ideas and actions propagate within the body politic. Propagation is not only at the root of propaganda as a concept, the dissemination of ideas and actions throughout culture unite many disparate thinkers who have addressed the topic from Herman and Chomsky's (Herman and Chomsky, 1988) structural work on the mass media, to Jacque Ellul's (1973) focus on action and Bakir et al's (2015) paper on persuasive communication. This is particularly useful in terms of digital propaganda, where peer to peer replication of ideas through networks lessens the need for centralised organisational structures whilst maintaining or even accelerating the propagation of particular ideas (Castells, 2012).

Memetics allows for the analysis of the proliferation of ideas in relation to the rhetorical techniques deployed to improve their replication. It also addresses the relationship between ideas encoded into a specific meme and other ideas, narratives and beliefs already identifiable within the environment in which such memes are replicating. The ethical considerations of both the techniques themselves and the ideas they seek to propagate are separated from the notion of propagation - and thus propaganda - allowing for a more dispassionate analysis. Bakir et al (2015) note that a variety of scholars have taken what they refer to as an 'a-critical' approach to propaganda analysis, as opposed to critical scholars who have focused on the abuse of propaganda, in particular its abuse by the powerful. In keeping with much of the 'a-critical' literature, the suggestion of a neutral definition for propaganda is in order to examine the ethical implications of each instance of propaganda and each propaganda technique individually and to allow considerations of ethics, deception and power to be carefully scrutinised rather than assumed as part of propaganda's definition. It is categorically not an assumption that propaganda as a neutral category is inherently benign, although it does extend the term to include the propagation of ideas which are both benign and positive. However, it is also more complex than the distinctions made by scholars such as Jowett and O'Donnell (1986) between black white and grey propaganda in which the honesty and transparency of the propaganda and the propagandist determines whether it can be seen as ethical or reprehensible.

Instead of using a simple good/bad dichotomy or gradient of deception for each propagandistic meme, each technique of propaganda - defined as a means by which the propagation of a meme can 
be facilitated - should be subject to ethical scrutiny. As a meme may contain multiple propaganda techniques, it's ethical status is likely to be more complex within such a system than in one with only three categories along a single spectrum - that of deception. As with Bakir et al's (2015) model the necessary ethical evaluation of propaganda can also address issues such as coercion, deception and incentivisation, but also allows for additional ethical considerations to be incorporated into the model as they arise within an analysis. This adaptability within the memetic model stems from the way in which memetics treats the rhetorical techniques which allow an individual meme's chances of replication to be improved. As unitary replicators which can be passed from person to person - not least through the pedagogical processes of teaching PR and marketing - these techniques can be seen as memes in their own right, and thus subject to evolutionary pressures and liable to adapt and change in response to them. This allows propaganda itself to be viewed as an evolving body of techniques for the propagation of memes, with new variations on techniques emerging in response to alterations the political and technological resources available, as well as in response to the other memes already present within a given environment. In the same way, ethical concerns surrounding the propagation of ideas may change depending on political, social and technological context (Sparkes-Vian, 2015, Sparkes-Vian as Vian, 2011).

\section{Methodology}

The methodology for this investigation was developed from a larger scale study on digital propaganda in the 2010 election (Sparkes-Vian, 2015) which dealt with both academic and popcultural memetic analysis. This paper focuses mainly on images (as opposed to text and video), which allows for better direct comparison with later 'reaction memes' intended to subvert and expose original posts by Britain First. This will include infographics combining simple text and images which can categorised as a type of pop-cultural or Internet meme, although the examples presented here are not all especially prolific examples of this category ${ }^{1}$.

Although much of the material within the data corpus could be characterised as pop-cultural ephemera, with the response memes in particular motived more by humour than the desire for serious political discourse, an understanding of the nature of Britain First's communication style, and popular opposition to it, can still be seen as a valuable subject for sociological research; not least because the consequences of the racist propaganda put out by Britain first have led directly to the violent harassment of British Muslims and may have contributed to the assassination of the MP Jo

\footnotetext{
${ }^{1}$ All figures for numbers of shares, likes and comments, including page likes are accurate as of May $15^{\text {th }} 2015$ and may not match those in screenshots taken at later dates.
} 
Cox by Britain First supporter Thomas Mair. The wider discussion within the case study will also address Britain First's Facebook page from a more general memetic perspective with a greater focus on the academic meme.

Qualitative memetics involves an analytical 'toolkit' of concepts within the literature on memetics in order to conduct a systematic analysis of memes and their environment, it was developed as a memetic adaptation of Jaiger and Maier's (2009) Foucaultian approach to Critical Discourse Analysis (CDA) and is intended to be an adaptive set of tools with which to address different research questions. The following 'tools' will be utilised within the forthcoming paper:

- Disaggregate the memeplex into its constituent alleles. Does the alteration of an allele change the meaning of the meme?

An allele in this context is a smaller constituent part of a larger meme which could theoretically be altered or replaced with alternative; for example, the content of text or the picture used within an infographic. The alteration of an allele can subvert the nature of a propagandistic meme.

- Is this a 'copy the product', or 'copy the instructions' meme?

Copy the product memes are replicated in their entirety - for example by sharing or cutting and pasting a picture or piece of text. Copy the instructions memes replicate by reproducing a meme (sometimes with alterations) from a specific or implicit set of instructions.

- Take the meme's eye view. What opportunities for replication exist within this environment?

Although a meme - as with any replicator - has no agency, it works by a simple rule: if a meme can replicate it will. The meme's eye view is a thought experiment which looks at a meme's environment in terms of opportunities for replication and pressures for alteration, in order to understand the spread and evolution of particular ideas, actions or texts. This is often done by endowing the meme with a pseudo-agency and treating it as though it 'intends' to replicate. This means understanding the environment in which a meme replicates and the way in which that environment affects that meme.

- Identify the propaganda techniques used to facilitate memetic replication within the data corpus. Have they been replicated from elsewhere?

There are a large number of techniques mentioned in the literature on propaganda which can facilitate a memes replication, from the use of emotive rhetoric to linguistic devices such paired contrasts and tripartite lists (Pratkanis and Aronson, 1991, Jowett and O'Donnell, 1986, Atkinson, 
1984, Lee and Lee, 1939, O'Shaughnessy, 2004). As these are imitable memes in and of themselves they can be expected to replicate and evolve. Identifying such techniques can provide insight into the replication of specific memes and identify new techniques of propaganda which might emerge in response to changes in the memetic environment.

This methodological approach involves the disaggregation of specific memes in order to isolate and analyse recognisable propaganda techniques identified within the wider propaganda literature as well as new techniques for ideological propagation which may have arisen; it also looks for the embedded ideological narratives which the replication of such memes facilitates and fits them analytically into wider political contexts. This relationship between an individual meme and the wider environment in which it replicates is a key aspect to understanding the spread of propaganda and the relative success of some memes over others. This study contends that memes exist in a dialectical relationship with their environment in which the body politic is created and defined by the ideas within it, whilst the ideas within the body politic have their replication facilitated or hindered by the proliferation of other compatible or incompatible memes within their surroundings. In the context of this case study the relevant environments include both the structure of Facebook as a network with specific rules and mechanisms for the replication of memes. One of the aspects associated with communication within this environment is the production of political echo chambers and 'trench warfare' dynamics, both of which can be seen within this case study. In addition, the political environment of contemporary UK politics and public opinion, including views expressed by more mainstream politicians and within traditional media form part of the environment in which memes from both Britain First and their online critics can spread, and are thus important contextual factors in understanding their relative replicator power.

\section{Case Study: Britain First}

Britain First is an extremist organisation and minor political party which splintered from the British National Party (BNP) in 2011 under the leadership of Jim Dowson. Dowson left the BNP in 2010 after a disagreement with Nick Griffin over the enforcement of a court order prohibiting the party from disallowing membership on grounds of race. He was also accused of sexual harassment by a female BNP activist (Stewart, 2010). Dowson left Britain first in 2014 to the leadership of another former BNP activist Paul Goulding, amidst newspaper reports that the two had clashed over Goulding's 
support for the tactic of invading Mosques and harassing worshipers (Sommerlad, 2014, Dearden, 2014b).

As a political party, the group has made little headway, largely lending their support to the United Kingdom Independence Party (UKIP) in most constituencies (Britain First, 2015a, Collins, 2015). However, their social media following, especially on Facebook has successfully outstripped all of the major UK political parties with over 720,000 page likes and an estimated online reach of over 20 million (Collins, 2015). The page itself publishes a combination of nationalistic, anti-immigration and Islamophobic rhetoric, militarism, promotion of Britain First merchandising and links to other rightwing groups such as the Knights Templar International (Britain First, 2015b). The use of the Internet by racist groups has long been an issue and as Jesse Daniels (2009) points out in relation to online white supremacist websites, this can often involve deceptive and covert forms of propaganda in which the origins and agenda of those involved are concealed. Something which makes the kind of counter-propaganda advocated (and anticipated) by Mason (2013a), considerably more difficult to do successfully.

In the case of Britain First, whilst their identity and agenda are not covert, they do deny the racist nature of their position, arguing instead that it is pro-British, anti-immigration and anti-Muslim, which they contend is not a racist position because it attacks a religion not a race and that "the only people [they] hate are the white leftwing politicians and journalists who are wrecking our beautiful country" (Britain First, 2015a, emphasis in original). A sobering statement given, that, during the trial of the white supremacist Thomas Mair, it was reported that he had repeatedly shouted 'Britain first' during his murder of 'white, left-wing politician', Jo Cox. The organisation also denies the existence of racism, because the word was "invented by a communist mass murderer, Leon Trotsky, to silence European opposition to "multi-culturalism" (Britain First, 2015a).

Often these narratives are embodied in infographics; these combinations of image and text have in turn given rise to a series of anti-Britain First memes and pages which produce various kinds of counter-propaganda. Some of these groups can be seen as part of a wider category of online activists who use humour to counter extremist right-wing messages - such as the English Disco Lovers (EDL) (2015), who organise disco themed flash mobs in protest against the far-right English Defence League (EDL) (2015). Others use more informative memes, seeking to expose the deceptive statements made by the group and encourage people to take action against them, and are joined in this goal by non-specific anti-fascist activists such as the author of the blog Another Angry Voice (Clark, 2015) which has repeatedly used a combination of infographic memes and more 
detailed articles to encourage people to report and critique Britain First, in an attempt to halt the spread of its propagandistic memes. These responses to Britain first are examples of the kind of corrective counter narrative which people such as Mason (2013a) and Zittrain (2008) have suggested, provides an effective bulwark against deceptive propaganda in the Internet age. However, this analysis will explore the limitations of this form of counter-propaganda, in the context of a wider memetic environment, conducive to many of the narratives propagated by Britain first; in particular the aggression and negative stereotyping which surrounds discussion of Islam, immigration and the welfare state.

\section{Discourses surrounding Immigrants, Islam and Welfare}

One of the underlying assumptions of those who have championed digital communication is that the democratisation of discourse provided by social media should have a positive impact on public communication including providing a bulwark against deceptive propaganda by elite groups (Mason, 2013b, Castells, 2012). However, in the case of Britain First, there is evidence of multiple instances of deceptive propaganda which utilise negative and inaccurate stereotypes of immigrants and Muslims in order to promote Britain First as a group, and in order to perpetuate the racist ideology which the organisation expounds. These intersect with narratives surrounding social security claimants in a manner which also reflects wider discourses on these topics propounded by the right-wing tabloid press and more mainstream political parties (Bhatia, 2014, Taylor, 2014, BBC News, 2015, Harkins and Lugo-Ocando, 2015). From the meme's eye view, these memes are replicating within a society replete with other memes which also attack such groups. If a Britain First meme attacking Muslims or immigrants encounters a mind which has already absorbed and accepted similar memes it will resonate with that person more easily than in a mind without them.

In terms of specific memes, Figure 1 represents a typical example of a Britain First 'copy the product' meme. Its success is measured in terms of its specific replication with absolute accuracy (although potentially alongside additional detractions) via Facebook's like and share features. It was shared 77,266 times, received 25,789 likes and approximately 2,100 comments which suggests a relatively high level of success at propagating. Although it should not be assumed that all of these interactions were endorsing the views expressed in the meme, within the context of Facebook's network each of them did serve to propagate it as interactions with posts on Facebook will appear in the newsfeeds of others on the network. 


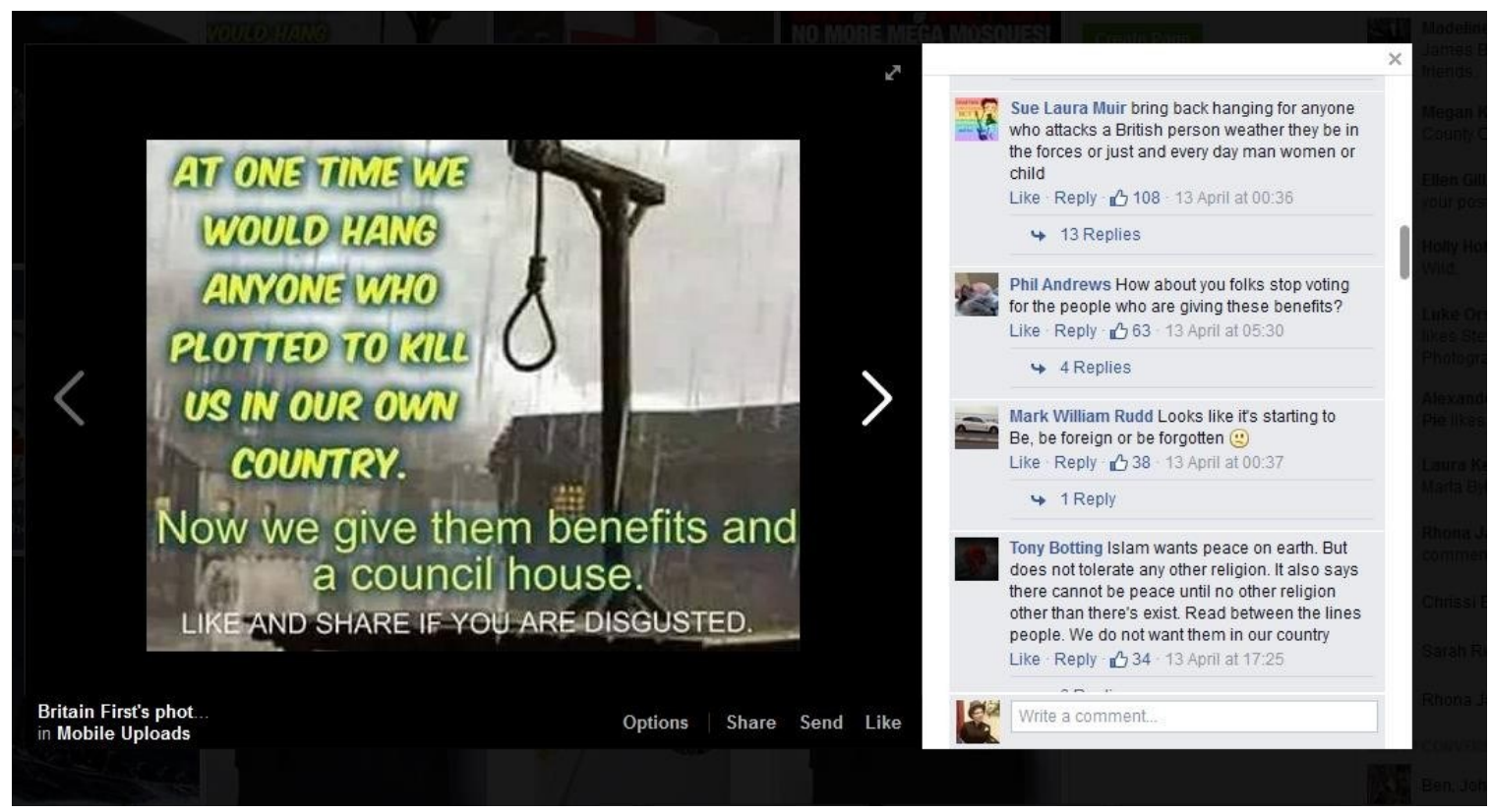

Figure 1: Screenshot of Britain First meme, originally posted April 15th 2015

Looking at this meme in terms of identifiable alleles (i.e. aspects of the meme which can be picked apart and swapped for others whilst remaining at least somewhat recognisable as a copy of the original), there are three distinct text groups and a background image. In keeping with its status as a 'copy the product meme' these do not conform to recognised infographic patterns from other popcultural memes such as the black border/image/text or 'keep calm' formulations (IMD, 2014). If an implicit set of instructions for the reproduction of this meme can be extracted from it, there is no evidence either on the Britain First page or on the Britain First counter-propaganda pages suggesting it has been replicated in this manner.

What can be identified are a selection of recognisable propaganda techniques from within the literature; for example, the use of paired contrast (Atkinson, 1984), comparing then and now as well as the othering discourse of ' $u s^{\prime}$ and 'them'. This othering is implicitly directed at immigrants as demonstrated by the phrase 'our own country', indicating that the dangerous and violent other who are provided with income and shelter by the state, are not part of that group, as indicated by the use of the word 'them'. The reference to 'kill[ing] us in our own country' relates to discourses surrounding terror and in the context of Britain First it can also be seen to specifically refer to the murder of the soldier Lee Rigby by Michael Adebolajo and Michael Adebowale (BBC News, 2014b), who claimed the action was in retaliation for the murder of Muslims by British soldiers engaged in military action in Muslim countries. As such the meme incorporates three of the group's favoured villains, Muslims, immigrants/foreigners and social security claimants, and excludes them from the 'us' of respectable British citizenry. 
The phrase 'Like and Share if you are Disgusted' represents common technique used within Britain First propaganda memes and an established one within digital propaganda more generally. In terms of older propaganda techniques, it combines the 'Bandwagon' notion of encouraging people to join in and replicate an idea which is already popular with the 'Testimonial' of the endorsement of a friend or acquaintance (Lee and Lee, 1939). However, it can also be seen as a specific technique 'Copy Me' which has arisen specifically within the web 2.0 era as a consequence of the ease with which information can be shared throughout a distributed network. This is in contrast to a hierarchical network, where a pronouncement from a centralised authority figure such as a mainstream politician or political party is distributed on mass via more traditional media.

The use of 'copy me' techniques can be seen at once as a positive - and more democratic development within the evolution of propaganda, and a potentially dangerous and deceptive one. Encouraging supporters to propagate a message on your behalf in this way helps to sidestep the distrust many feel towards authority figures, especially established politicians (Sparkes-Vian, 2015), this is another theme frequently highlighted within Britain First posts, which often exhibit hostility towards mainstream political figures irrespective of party (Britain First, 2015b). It also utilises the ease with which the Facebook network allows people to propagate information throughout their peer groups, reducing the organisational and administrative burden on the propaganda source and allowing ideas to flow from less powerful organisations, as well as those already powerful.

However, 'copy me' techniques also provide the opportunity to obscure the origins of a piece of information, something which is problematic in mainstream politics, where enthusiastic supporters become the face of a campaign, whilst more traditional campaign strategists and spin doctors remain in charge. When dealing with groups such as Britain First, the use of 'copy me' techniques in this manner can function on a similar way to the use of cloaked websites as discussed by Daniels (2009), obscuring the nature of the organisation who originally posted the meme and thus gaining likes and shares from those who would not otherwise agree with many of their views. This is the case with Britain First's use of Lee Rigby's image against the express wishes of his family and their use of the Royal British Legion's poppy symbol and the royal crest (Dearden, 2014a, BBC News, 2014a).

The capacity of information to propagate effectively without the need for excessive, expensive administrative control at the centre is one of the reasons that social networking has been hailed as a democratising force for communication and a means whereby centralised or elite propaganda can be challenged (Castells, 2012, Gerbaudo, 2012, Mason, 2013b, Mason, 2013a). However, this example demonstrates another side to this form of communication: the replication of extremist 
views and false or misleading disinformation which resonate with widespread social ignorance. It also raises questions about the notion that propaganda should specifically be 'organised' communication. Much of the information which passes through Britain First is shared from other places and replicated virally without centralised organisation (Britian First, 2015). This is a common distribution method for virally grown movements on both the left and right, and whilst Britain First do have a hierarchical structure and identifiable leaders, movements on the left such as the Indignadas/os in Spain and the global Occupy movement have specifically rejected the notion of leadership. Although some, such as Paolo Gerbaudo (2012) have disputed the true horizontalism of such movements as a whole, the replication of individual pieces of viral propaganda, can be generated ad hoc by an individual without need for any form of explicit co-ordination, even if copies of it are also replicated via more clearly organised distribution points such as that provided by Britain First. For this reason, it may be that propagation is preferable to organised persuasion as a framework for understanding digital propaganda.

Figure 2 further highlights the theme also present in Figure 1; the (inaccurate) claim that foreign nationals and immigrants are more likely than their British counterparts to be in receipt of social security support. This is a common theme within the posts on Britain First's Facebook page. Like Figure 1 it is also a 'copy the product' meme with no obvious pattern of substitutable alleles which can be related to other pop-cultural or Internet memes. The use of copy the product memes is common but not universal on Britain First's page, which also includes occasional examples of the 'black border/image' style meme and a variation of 'Je Suis Charlie' in the wake of the attack on the French magazine (IMD, 2014, Britain First, 2015b). Figure 2 was considerably less successful than Figure 1, amassing only 2,878 likes and 1,886 shares; however, it does illustrate something significant in relation to the counter-propaganda which Britain First inspired. Errors in spelling and grammar, such as the grammatically incorrect use of 'is' in Figure 2, are reoccurring themes amongst contributors to Britain First's page, and repeatedly lampooned by their detractors. The use of humour as a propaganda technique can be an effective facilitator for replication, although the appeal is likely to be restricted to those who are already hostile to Britain First's message (Shifman, 2012, Sparkes-Vian, 2015). 


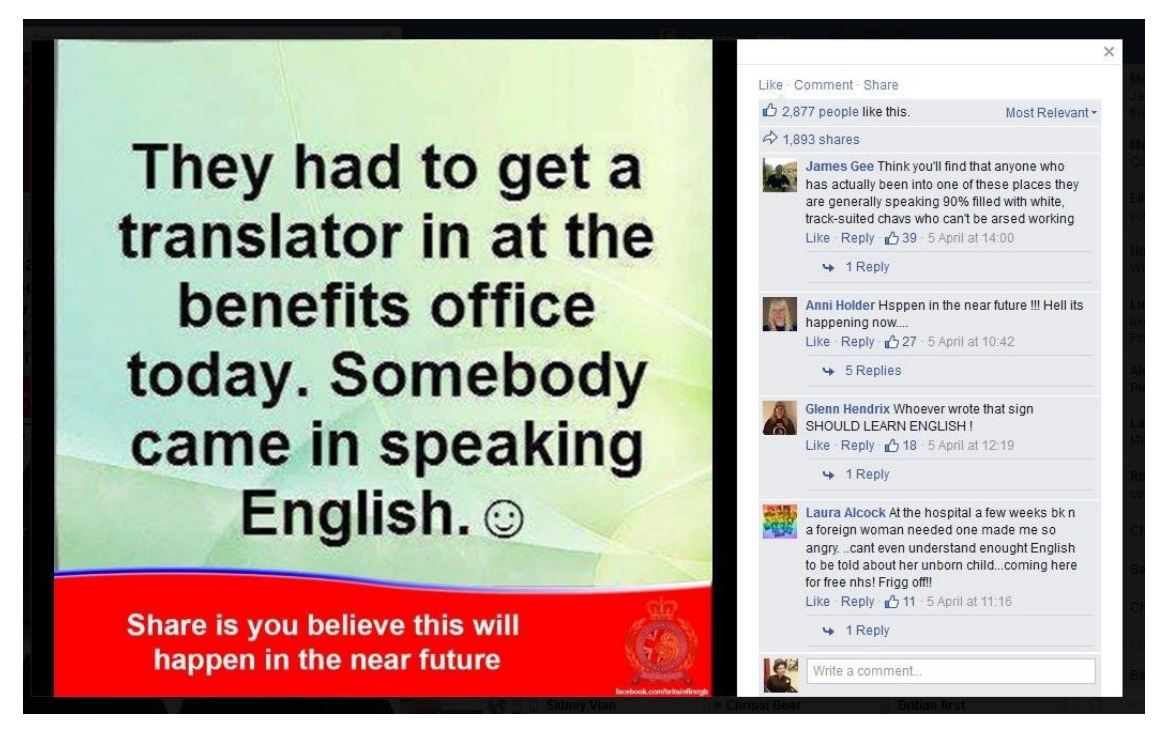

Figure 2: Screenshot of Britain First meme, highlighting poor spelling - a common theme in anti-Britain First memes.

The popularity of Britain First and the propagation of the narratives espoused in their memes can be understood in terms of propaganda but not necessarily in terms of persuasion. The automatic conflation of propaganda with persuasive speech is problematic, not because propaganda is never persuasive, but because it ignores propaganda's role in re-affirming beliefs which are already held by the individuals consuming the propaganda. This is the case not only with this form of digital propaganda which is intended to be shared by sympathisers and supporters of Britain First's page, but also with 'live action' political propaganda such as the formulaic protest chants used during marches and demonstrations. This fulfils a role similar to that of a marker scheme symbol (see Blackmore, 1999) of helping to identify members of a specific group and to differentiate them from outsiders. It is also possible that the creation of structured ideological groups with an inside and outside (in memetic terms this is referred to as an institutional memetic construct or institutional memeplex) can create distinct memetic environments in which the selection pressure on specific memes is altered by the ready acceptance of the basic premises of the ideology (Sparkes-Vian, 2015). This can be seen as an effect not only of ideological proliferation, but also of Facebook as a network which can cause the clustering of political opinion as a consequence of the relationship between ideology, social networks and friendship groups (McPherson et al., 2001).

When examined through the meme's eye view it appears that Britain First's posts are not necessarily serving as persuasive tools but as affirmations of ideas which are already popular. A substantial majority $(77 \%)$ for example believe that immigration is too high and should be reduced, with $55 \%$ saying the reduction should be substantial (Kitchen, 2009). Rather than trying to persuade, memes such as Figures 1 and 2 utilise the presence of anti-immigration and racist narratives to facilitate their own replication. Also, despite suggestions that the online 'hive mind' should produce truth and 
weed out disinformation, the presence of such narratives counteracts the importance of truth as a selection pressure, as topics such as immigration and welfare are areas of mass ignorance. For example, research conducted by University College London (Dustmann and Frattini, 2013) shows that immigrants in are in fact $45 \%$ less likely to receive benefits than their British counterparts and 3\% less likely to live in supported housing. Additional research for the Royal Statistical Society (2013) shows that those polled consistently over-estimated the level of migration (believing it to be double the actual figure even when unregistered migration was accounted for) as well as overestimating the number of Muslims, the level of benefit fraud and the portion of the Social Security budget spent on Jobseekers Allowance in relation to pensions.

This is an environment in which the ideas embodied within Britain First's memes already resonate with a significant portion (and in some cases a majority) of the population and their codification in easily replicable memes merely facilitate the replication of such ideas. The argument that in a digital environment "propaganda becomes flammable" (Mason, 2013a) therefore appears problematic and the digital world appears to merely exacerbate already existing ignorance. However explicit racism of the kind often present on Britain First's page is less acknowledged with two thirds of the population denying any racial prejudice and only 3\% admitting to significant prejudice (NatCen, 2014) perceptions of racist attitudes by minority groups also becoming less prevalent (Kitchen, 2009). Even Britain First deny that their position is racist in a manner comparable with practices by US far right groups discussed by Daniels (2009). It is therefore less than surprising that, in keeping with trends noticeable in both political and apolitical studies on Internet memes, the propaganda produced by Britain First spawned a selection of critical response memes which can be analysed as a form of counter-propaganda. In such an environment, counter-propaganda memes attacking Britain First have also found many opportunities for replication within the Facebook network.

\section{Satire and Critique as Counter-Propaganda}

In their study of the diffusion of an Internet meme in the form of an online joke, Shifman and Thelwall (2009) noted that the meme they were studying developed a distinctive 'call-response' pattern. In that case, as the initial joke revolved around stereotypical gender roles that pat tern took the form of a male/female call-response. In Sparkes-Vian's (2015) analysis of Internet memes in the 2010 election a similar call-response pattern was noted on a much smaller scale with reference to major party memes in which initial propaganda images constructed by major parties were co-opted and adapted to propagate anti-party messages. In the case of the Conservative Party's billboard campaign posters the satirical response from www.mydavidcameron.com (Singer, 2010) arguably 
became a more successful meme than the original propaganda posters with a wide variety of antiConservative iterations proliferating online.

Although a more detailed, quantitative analysis would be needed to confirm this, the initial evidence is that the Britain First memes have followed the pattern noted by Shifman and Thelwall in that the secondary, counter propaganda memes have been less successful at proliferating than Britain First's initial posts. Whilst a number of Facebook pages such as Exposing Britain First (2015) (44,824 likes), Fuck Britain First (2015) (12,423 likes), Britian First (2015b) (16,323 likes), Britain Furst (2015) (114,818 likes) and Report Britain First (2015) (7,397 likes), have been established with the specific goal of producing and distributing anti-Britain First memes, none of these sites have come close to competing with the reach of Britain First itself and its 720,461 page likes.

The tactics of these groups include the organised reporting of Britain First memes deemed to have broken Facebook's terms and conditions, as well as the use of satirical and critical memes which attack either general themes or specific posts from Britain First's page. In terms of the first tactic there appears to have been a certain amount of success. Specifically, these groups targeted the practice of using anti-animal abuse memes as a means to raise funds for the groups and spread Britain First's reach beyond the scope of the far right (Clark, 2015). These memes typically took the form of an image of an injured animal captioned with slogans such as 'Like and Share if you are against animal cruelty'ㄹ (Clark, 2014). The graphic nature of the images allowed those opposed to Britain First to request their removal on the grounds that the breached Facebook's community standards, a tactic which did not work when complaining about demonstrably false and aggressive memes about Muslims, Social Security claimants or migrants (Report Britain First, 2015).

The use of an external coercive authority in order to halt the spread of memes can be seen as a form of citizen generated censorship - in this case deployed against a deceptive and manipulative form of propaganda. It is comparable to other legalistic tactics such as the pursuit of Britain First under copyright legislation for the use of the Royal British Legion poppy symbol and the crown (BBC News, 2014a, Dearden, 2014a). Given the nature of the material being prohibited the negative associations attached to the notion of coercion within the Bakir et al (2015) may be problematic or at least require further discussion of the role of coercion and counter-coercion in cases where forms of censorship are deployed against deceptive or damaging forms of propaganda. Using these tactics as a means to limit the spread of a contrary meme can also be considered an imitable propaganda

\footnotetext{
${ }^{2}$ Most of these images have been removed but a copy of one can be found via Another Angry Voice as cited above.
} 
technique and one which Britain First have used themselves used to organise complaints to Channel 4 over a docudrama which criticised UKIP (Saul, 2015).

A second tactic which was alluded to earlier is the use of satire, in particular frequent allusions to the poor grammar and spelling which is a common feature of Britain First's memes. This is widely evident in page names such as Britain Furst and Britian First and is also a common feature of memes distributed by Fuck Britain First. For example, Figure 3 shows the combination of poor grammar as well as a comically exaggerated version of British nationalism in relation to 'English elephants' designed to highlight the absurdity of the narratives within Britain First's memes. The use of satire as a technique for propagation is easily understood from the meme's eye view. Racist narratives such as those perpetuated by Britain First still have a substantial pool of receptive minds in which to replicate and can therefore spread without the need for much centralised co-ordination. However, the political environment is heterogeneous and also contains many minds which are actively hostile to the ideas Britain First espouses. This opens up a replication opportunity for memes of counterpropaganda such as Figure 3 which use the increased replicator power of humour to subvert Britain First's message. It also includes the instruction to provide 'help and money' as a common criticism of Britain First by critical commentators is their heavy promotion of merchandising (including the use of the Crown and Poppy previously mentioned) in order to perpetuate their extremist ideology (Clark, 2015, Exposing Britain First, 2015, Report Britain First, 2015).

The use of merchandising as a propaganda technique is notable within the political mainstream and has been a common feature of US elections for over a decade. Recent years have seen attempts made to follow suit in the UK with the Conservatives offering merchandising from 2010 and the Liberal Democrats seeing independent retailers selling 'I agree with Nick' t-shirts during the high point of their popularity in that contest (Sparkes-Vian, 2015). As with other techniques observed here this is less to do with persuading people externally and more to do with identification with an in group. Merchandising, in its utilisation of the Bandwagon and Testimonial techniques of propaganda is a positive variation on this theme, reminding supporters that their views are not isolated, an especially useful technique for extremist groups with Britain First adopting both their own logo, and also utilising more widespread and popular symbols such as the national flag on their merchandising. 


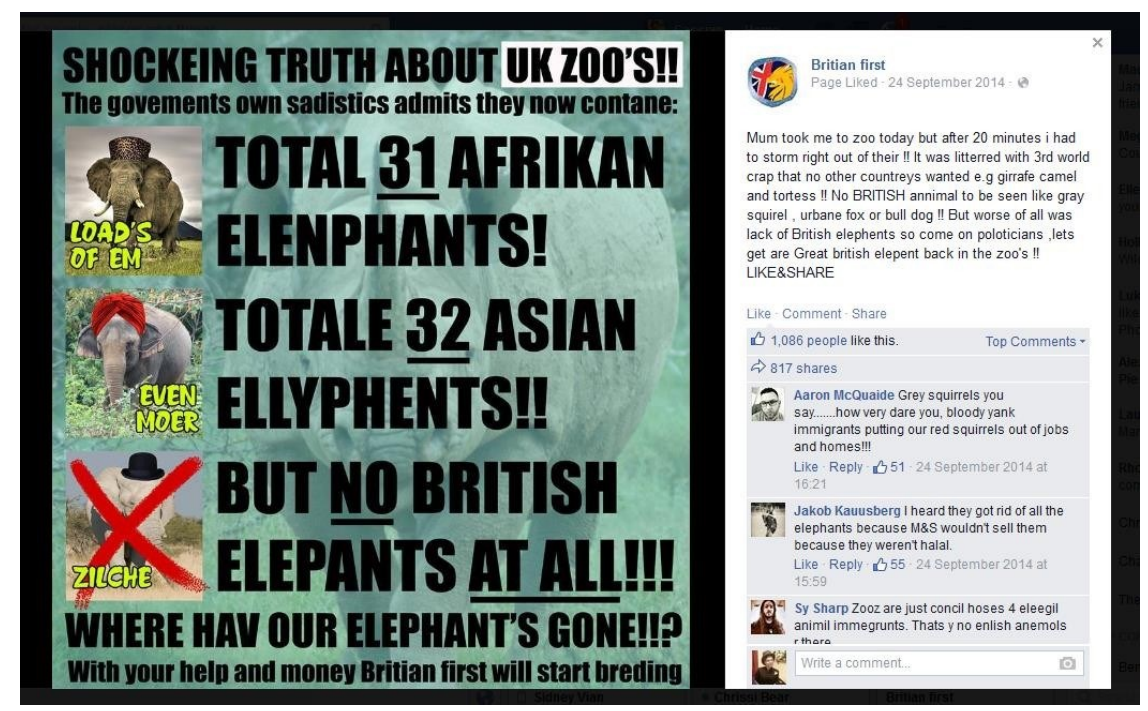

Figure 3: Satirical post from Britian First

The final tactic used by the counter-propaganda sites is possibly the least successful, it involves the generation of explanatory memes which highlight inconsistencies in claims made in specific Britain First posts. This is a tactic used in particular by Report Britain First, for example creating memes which question Britain First's claims to have slept on the streets in solidarity with homeless veterans by analysing the times at which their photos were taken. In keeping with the analysis of Internet memes undertaken by Shifman (2012), the satirical counter-propaganda memes were considerably more popular with typical analytical memes only getting a handful of shares and likes as humour was a common indicator of popularity within her study, whilst political memes had a more difficult time getting replicated. This is interesting as well from a definitional perspective, as these analytical memes are the only ones which specifically clearly seek to persuade, with the majority of the propaganda memes from both Britain First and their detractors seeking instead to appeal to a base of existing sympathisers. The element of persuasion, to the extent to which it is present, comes in the form of persuading those already convinced of the rightness or wrongness of Britain First's position to replicate their propaganda or the counter-propaganda which seeks to undermine and discredit it. Whilst the memes from the satirical sites and the censorship tactics have elements of 'copy the instructions' to them, these analytical memes tend to be fairly specific to individual instances of Britain First propaganda, rather than following a more longstanding imitable pattern. However, unlike Britain First's own posts they are not as widely shared throughout the network.

\section{Conclusion}


The memes distributed via Britain First's Facebook page have propagated a selection of extremist narratives, notably in connection with race and Islam, with considerable success. This may seem surprising given that over two-thirds of the British public deny having any racial prejudice (NatCen, 2014); however, the specific areas in which they perpetuate memes tap into views and narratives which are widespread throughout contemporary UK culture. Evidence that these narratives, whilst prevalent do not reflect reality has not prevented the spread of these ideas. Despite hopeful assertions by some scholars, the activities of Britain First suggest that in some cases, deceptive propaganda championed by elite groups such as Conservative politicians and right-wing newspapers, can in fact be supported and exacerbated by digital means rather than automatically challenged.

Although there is considerable evidence of such challenges occurring online, the proliferation of counter-propaganda against Britain First has not been as effective as the propagation of the group's page itself. In addition, despite some successes in terms of the repression of the tactic of spreading their reach through anti-animal cruelty memes, much of the counter-propaganda shares with Britain First's own posts, a sense of preaching to the converted. A call-response pattern emerges where Britain First generates memes which appeal to those who are critical of immigration and multiculturalism and other groups critical of Britain First produce material which subverts and satirises those memes for the benefit of those critical of Britain First and its political agenda. In both instances, it is notable that whilst each meme can be understood in terms of propaganda, the only aspects which seek to persuade are the calls to action, sometimes to attend demonstrations, but more frequently simply to perpetuate the propaganda of each group. The only examples from this case study of memes which really intended to persuade people to change their ideas, were those which critically addressed memes originally posted by Britain First and challenged their content. These were the least successful at replicating, suggesting a need to qualify and contextualise the role of persuasion in defining propaganda in this context.

Similarly, although Britain First's organisation and Facebook page can be seen as evidence of the organised propagation of ideas, the distribution of specific memes online is much more chaotic and requires little in the way of traditional organisational structures, although their presence can certainly facilitate the spread of specific memes by congregating likeminded people together in a space where they can easily share them throughout their own networks. Like persuasion, organisation is a possible but not necessary aspect of digital propaganda whereas propagation remains central to understanding the spread of ideas and ideological memes online. 
ATKINSON, M. 1984. Our Masters' Voices, London, Methuen.

BAKIR, V., HERRING, E., MILLER, D. \& ROBINSON, P. 2015. Rethinking Propaganda as a Sub-Set of Organised Persuasive Communication. Organised Persuasive Communication (In Press).

BAUCKHAGE, C., KERSTING, K. \& HADIJI, F. 2013. Mathematical Models of Fads Explain the Temporal Dynamics of Internet Memes. Seventh International AAAI Conference on Weblogs and Social Media Cambridge, Massachusetts, USA.

BBC NEWS. 2014a. Britain First not authorised to use image of Crown. BBC News [Online]. Available: http://www.bbc.co.uk/news/uk-politics-28967196 [Accessed 19th August 2015].

BBC NEWS. 2014b. Lee Rigby murder: Adebolajo and Adebowale jailed. BBC News [Online]. Available: http://www.bbc.co.uk/news/uk-26357007 [Accessed 5th August 2015].

BBC NEWS. 2015. David Cameron: 'Swarm' of migrants crossing Mediterranean. BBC News [Online]. Available: http://www.bbc.co.uk/news/uk-politics-33714282 [Accessed 6th August 2015].

BHATIA, M. 2014. Researching 'Bogus' Asylum Seekers, 'Illegal' Migrants and 'Crimmigrants'. In:

LUMSDEN, K. \& WINTER, A. (eds.) Reflexivity in Criminological Research. Basingstoke: Palgrave MacMillan.

BLACKMORE, S. 1999. The Meme Machine, Oxford, Oxford University Press.

BRITAIN FIRST. 2015a. Britain First [Online]. Available: www.britainfirst.org [Accessed 4th August 2015].

BRITAIN FIRST. 2015b. Britain First (Facebook) [Online]. Facebook: Facebook Inc. Available: https://www.facebook.com/OfficialBritainFirst?fref=ts [Accessed 4th August 2015].

BRITAIN FURST. 2015. Britain Furst (Facebook) [Online]. Facebook: Facebook. Available: https://www.facebook.com/BritiainFurst?fref=ts [Accessed 5th August 2015].

BRITIAN FIRST. 2015. Britian First (Facebook) [Online]. Facebook: Facebook. Available: https://www.facebook.com/britianfirst?fref=ts [Accessed 5th August 2015]

CASTELLS, M. 2012. Networks of Outrage and Hope: Social Movements in the Internet Age, Cambridge, Polity Press.

CHRISTENSEN, H. S. 2011. Political activities on the Internet: Slacktivism or political participation by other means? First Monday, 16. 
CLARK, T. 2014. 12 Things You Should Know About Britain First. Another Angry Voice [Online]. Available from: http://anotherangryvoice.blogspot.co.uk/2014/06/12-things-britain- first.html [Accessed 7th June 2014 2015].

CLARK, T. G. 2015. Another Angry Voice [Online]. Available:

http://anotherangryvoice.blogspot.co.uk/ [Accessed 5th August 2015].

COLLINS, M. 2015. The truth about Britain First - the one-man band with a knack for Facebook. The Guardian [Online]. Available: http://www.theguardian.com/commentisfree/2015/feb/25/truthbritain-first-facebook-far- right-bnp [Accessed 5th August 2015].

DANIELS, J. 2009. Cloaked websites: propaganda, cyber-racism and epistemology in the digital era. New Media \& Society, 11, 659-683.

DAWKINS, R. 2006a. The Selfish Gene (30th Anniversary Edition), Oxford, Oxford University Press. DAWKINS, R. 2006b. Viruses of the Mind. The Richard Dawkins Foundation for Reason and Science [Online]. Available: http://richarddawkins.net/articles/98 [Accessed 25th July 2011].

DEARDEN, L. 2014a. Britain First accused of 'hijacking' the poppy ahead of Remembrance Day. The Independent [Online]. Available: http://www.independent.co.uk/news/uk/home- news/britain-firstaccused-of-hijacking-the-poppy-ahead-of-remembrance-day-9841107.html [Accessed 19th August 2015].

DEARDEN, L. 2014b. Britain First founder Jim Dowson quits over mosque invasions and 'rac ists and extremists'. The Independent [Online]. Available: http://www.independent.co.uk/news/uk/homenews/britain-first-founder-jim-dowson- quits-over-mosque-invasions-and-racists-and-extremists9632770.html [Accessed 5th August 2015].

DENNETT, D. 1996. Darwin's Dangerous Idea: Evolution and the Meanings of Life, London, Penguin Books.

DENNETT, D. 2003. Freedom Evolves. London: Penguin Books.

DUSTMANN, C. \& FRATTINI, T. 2013. The Fiscal Effects of Immigration to the UK. Centre for Research and Analysis of Migration Discussion Paper Series. Centre for Research and Analysis of Migration, University College London.

EDMONDS, B. 2005. The revealed poverty of the gene-meme analogy - why memetics per se has failed to produce substantive results. Journal of Memetics - Evolutionary Models of Information Transmission, 9 . 
ELLUL, J. 1973. Propaganda: The formation of men's attitudes, New York, Vintage Books. ENGLISH DEFENCE LEAGUE. 2015. English Defence League [Online]. Available: http://www.englishdefenceleague.org/ [Accessed 5th August 2015]. ENGLISH DISCO LOVERS (EDL). 2015. English Disco Lovers (EDL) [Online]. Facebook: Facebook. Available: https://www.facebook.com/englishdiscolovers?fref=ts [Accessed 5th August 2015]. EXPOSING BRITAIN FIRST. 2015. Exposing Britain First [Online]. Facebook: Facebook. Available: https://www.facebook.com/Exposing0BritainOFirst?fref=ts [Accessed 5th August 2015].

FUCK BRITAIN FIRST. 2015. Fuck Britian First (Facebook) [Online]. Facebook: Facebook. Available: https://www.facebook.com/pages/Fuck-Britain-First/881936085168325?fref=ts [Accessed 5th August 2015].

GERBAUDO, P. 2012. Tweets and the Streets: Social Media and Contemporary Activism, London, Pluto Press.

HARKINS, S. \& LUGO-OCANDO, J. 2015. How Malthusian Ideology crept into the Newsroom: British tabloids and the coverage of the 'underclass'. Critical Discourse Studies, In Press.

HERMAN, E. S. \& CHOMSKY, N. 1988. Manufacturing Consent: Political Economy of the Mass Media, New York, Vintage.

IMD. 2014. Internet Meme Database: Know Your Meme [Online]. Available: http://knowyourmeme.com/ [Accessed 10th June 2014 ].

JAGER, S. \& MAIER, F. 2009. Theoretical and methodological aspects of Foucauldian critical discourse analysis and dispositive analysis. In: WODAK, R. \& MEYER, M. (eds.) Methods of Critical Discourse Analysis. Second Edition ed. London: Sage.

JOWETT, G. S. \& O'DONNELL, V. 1986. Propaganda and Persuasion, London, Sage.

KITCHEN, S. 2009. Citizenship Survey. NatCen.

LEE, A. M. \& LEE, E. B. 1939. The Fine Art of Propaganda: A Study of Father Coughlin's Speeches, New York, Harcourt, Brace and Company.

MASON, P. 2013a. Why it's still kicking off everywhere. London: Verso.

MASON, P. 2013b. Why it's still kicking off everywhere (E-book). London Verso.

MCPHERSON, M., SMITH-LOVIN, L. \& COOK, J. M. 2001. Birds of a feather: Homophily in social networks. Annual Review of Sociology, 415-444. 
NATCEN 2014. 30 years of British Social Attitudes, self-reported racial prejudice data. NatCen.

O'SHAUGHNESSY, N. J. 2004. Politics and Propaganda: Weapons of Mass Seduction, Manchester, Manchester University Press.

PRATKANIS, A. \& ARONSON, E. 1991. Age of Propaganda: The everyday use and abuse of persuasion, New York, W. H. Freeman and Company.

REPORT BRITAIN FIRST. 2015. Report Britain First [Online]. Facebook: Facebook. Available: https://www.facebook.com/reportbritainfirst?fref=ts [Accessed 5th August 2015].

RINTEL, S. 2013. Crisis memes: The importance of templatability to Internet culture and freedom of expression. Australasian Journal of Popular Culture, 2.

ROYAL STATISTICAL SOCIETY 2013. Perils of Perception. London: Royal Statistical Society.

SAUL, H. 2015. Britain First claims to be behind thousands of complaints to Ofcom over 100 Days of Ukip. The Independent [Online]. Available: http://www.independent.co.uk/news/uk/homenews/britain-first-claims-to-be-behind-thousands-of-complaints-to-ofcom-over-100-days-of- ukip10067709.html [Accessed 19th August 2015].

SHIFMAN, L. 2012. An anatomy of a YouTube meme. New Media \& Society, 14, 187-203.

SHIFMAN, L. \& THELWALL, M. 2009. Assessing global diffusion with Web memetics: The spread and evolution of a popular joke. Journal of the American Society for Information Science and Technology, $60,2567-2576$.

SINGER, C. 2010. About Us [Online]. Available: http://mydavidcameron.com/about [Accessed 14th October 2013].

SOMMERLAD, N. 2014. Britain First founder quits over mosque invasions which attract "racists and extremists". The Mirror [Online]. Available: http://www.mirror.co.uk/news/uk-news/britain- firstfounder-quits-over-3923810 [Accessed 5th August 2015].

SPARKES-VIAN, C. 2015. The Evolution of Propaganda: Investigating Online Electioneering in the UK General Election of 2010. PHD, De Montfort University.

STEWART, S. 2010. BNP money man quits after model accuses him of groping her in hotel room. Daily Record [Online]. Available: http://www.dailyrecord.co.uk/news/scottish-news/bnp-moneyman-quits-after-1074247 [Accessed 5th August 2015]. 
TAYLOR, C. 2014. Investigating the representation of migrants in the UK and Italian press: A crosslinguistic corpus-assisted discourse analysis. International Journal of Corpus Linguistics, 19, 368-400. VIAN, C. 2011. Memes of Propaganda: The Birth of the Citizen Propagandist? Political Studies Association Annual Conference 2011. London.

WARD, J. 2008. The online citizen-consumer: addressing young people's political consumption through technology. Journal of Youth Studies, 11, 513-526.

WENG, L., FLAMMINI, A., VESPIGNANI, A. \& MENCZER, F. 2012. Competition among memes in a world with limited attention. Sci. Rep., 2.

ZITTRAIN, J. 2008. The Future of the Internet - and how to stop it, New Haven and London, Yale University Press. 